\title{
Effect of Insecurity of School Environment on the Academic Performance of Secondary School Students in Imo State
}

\author{
Ojukwu, M.O. \\ College of Education, Michael Okpara University of Agriculture, Umudike, Nigeria \\ E-mail: floxymark2008@yahoo.com
}

Received: 07-01-2017

Accepted: 28-01-2017

Published: 31-01-2017

doi:10.7575/aiac.ijels.v.5n.1p.20

URL: http://dx.doi.org/10.7575/aiac.ijels.v.5n.1p.20

\begin{abstract}
The major aim of this study was to investigate the effect of insecurity of school environment on the academic performance of secondary school students in Imo state, Nigeria. A total of 1000 made up of 500 each of male and female students responded to a self-structured validated questionnaire designed for the study. Two research questions and two hypotheses were formulated to guide the study. Means and standard deviations were calculated to answer the research questions and independent samples t-tests were used for testing the hypotheses. Major findings revealed that insecurity of school environment significantly affects the academic performance of secondary school students while students' gangsterism, smoking of Indian hemp, abusing other hard drugs, cult and related violent activities were some of the factors that constituted insecurity of the school environment which eventually cause boys to leave school and join trading while leading girls to drop out and settle for marriage. Based on the findings, it was recommended that owners of schools and other stakeholders in education should take bold steps to fence and protect school environments from intruders to ensure safety of the students.
\end{abstract}

Keywords: Effect of insecurity, school environment, Academic performance, secondary school students and Imo state

\section{Introduction}

The importance of education has been adequately discussed in many fora and in different literature (NwanneNzewunwa, 2009; Ojukwu \& Nwanma, 2015 and Ojukwu \& Onuoha, 2016; Osanti, 2012). It is in realization of the importance of education of the child that the government of the Federal Republic of Nigeria in its 1999 constitution made a declaration of the right of every Nigerian child to education, irrespective of gender, tribe, religion or race. It makes sense to state that the lofty vision of education as enunciated in the constitution of the Federal Republic of Nigeria would be realized in a serene and conducive school environment. According to Lehr (2014), the noble goals of education can never be achieved in a vacuum. They would be achieved in a conducive and peaceful school environment. If there is a feeling of insecurity within and outside the school environment, both students and teachers are likely to be deterred and this may inhibit academic performance of the students.

The concept of school environment has been variously defined by various researchers (Miller \& Cunnighan, 2011; Obi, Johnson \& Lawani, 2004). According to Obi et al., (2004) school environment connotes all human and material resources available in the school, in which a child can see, hear, touch, smell, taste, feel and respond to. Also Miller and Cunnighan (2011) maintained that the issue of school environment is multi-dimensional. According to them it possesses the physical, social, and academic demons. They listed the physical dimension to include the appearance of school building and classrooms, libraries, laboratories, hostels, sporting games and recreational facilities. Others according to them include instructional materials, school size and ratio of student teacher in the classroom. Others are the order and organization of classrooms in the school, the position of chalk or whiteboard and the availability of resources to afford safety and comfort. They also listed the social dimension aspect to include the quality of interpersonal relationship between and amongst students, teachers and administrators, equitable and fair treatment of students by teachers and staff, the degrees of competition and social comparison amongst students and the degree to which students and teachers contribute to the decision making process of the school. Miller and Cunnighan (2011) also added that the academic dimensions of the school environment include the quality of instruction given to the students and the teachers expectations for good achievements from students. School environment or climate refers to the way students and staff feel about being at school each day. It could be conceived as settings in which young people can learn a sense of membership in and obligation to a group (Glew, Fan, Katon, Rivera \& Kernic, 2005). In such environments and climates, we expect that people will be more concerned about fellow students and more inclined to dissuade them from engaging in behaviors that might endanger themselves or others. In this respect, Mcevoy and Werner, (2000) concluded that feelings of trust and respect for students and teachers influenced school environment and Glew et al., (2005) reported that improving student behavior and academic performance generally requires changing school climate. Also a sense of competency will often emerge in an environment that is fair and consistent which will in turn provide 
approximate academic support and expectations (Grifft, 1999). Besides, to support students' sense of belonging, the school climate must demonstrate interest in individual students and include emotional support by teachers and other students (Way, Reddy \& Rhodes, 2007). Empirical studies have suggested that student's perceptions of academic support, behavior management, teacher social support, and peer social support are strongly associated with their behavioral adjustment (Wang, 2010). Academic support is the extent to which the school emphasizes and creates a supportive learning environment with huge academic expectations and many opportunities for reinforcement (Kuperminc, Leadbeater \& Blatt, 2001). Students who perceive strong academic support in school are more likely to be accordingly motivated and have fewer behavioral problems (Wang, 2010). Conversely, students who experience repeated failures in academics are less inclined to perceive their school as academically supportive and may reduce their commitment to student roles and their motivation to perform well and increase school problem behavior (McEvoy \& Werner, 2000).

Attention to the behavior management of students in public school has been shown to be associated with lower levels of problem behavior (Kuperminc et al., 2001). School behavior management involves the extent to which the school provides clear and consistent rules and discipline and adults treat students in a fair and equitable manner. Students who report that their schools establish, communicate, and enforce a fair discipline system with clear rules and consequences have fewer problem behaviors and avoid victimization (Griffith et al., 2000). In essence, the quality of interpersonal relationships in school including student teacher relationships and peer relationships may be an essential role in the development of student problem behaviors and academic performance. Students who perceive that teachers are supportive, responsive and care about them have better academic performance and fewer behavioral problems (Wang, 2010). It makes sense to state that school environment where the situations above are positive may impact positively on the academic performance of the students and vice versa. Hypothetically, therefore, the above environment will have a positive impact on the performance of students in schools (Ojukwu \& Nwanma, 2015).

However, one of the major issues that seem to bother students, parents and stakeholders in Nigeria today is the academic performance of the students. According to Fehintola (2009), poor academic performance of students in internal and external examinations is one of the problems and challenges facing the educational system in Nigeria today. Education itself helps individuals to adapt to a new environment (Ojukwu, 2016). In Nigeria, education is seen as one of the means of getting to the top hierarchy in any endeavor. Thus, poor academic performance usually brings about sadness and frustration to the individual concerned and to his/her parents as well as other members of the family. As a matter of fact, it gives parents and students feelings of satisfaction and joy when children excel academically (Fehintola, 2009; Ojukwu, 2016).

Academic performance entails that students are required to maintain a satisfactory academic record and meet the obligations of the courses they are enrolled (Ojukwu, \& Nwanma 2015). Academic performance is the outcome of education, the extent to which a student achieved the educational goals. Put in another way, good academic performance is the personal comportment and commitment of the student to actualize his/her academic purposes which may include concentrating on one's studies, having confidence to success oriented academic activities in school and so in other to maximally actualize his life career or dream (Olofintoye, 2005).

Good or bad academic performance can make or mar the goals of a student's life as well as the national goals and development. A good academic performance would bring about the motivation and enthusiasm the student needs to attain a high academic standing when compared with his/her mates. It brings about resilience and makes the student success-oriented (Morgan, 2002).

The performance of Imo State Secondary School students in external examinations such as the Senior Secondary School Certificate conducted by the West African Examination Council (WAEC) and National Examination Council (NECO) appears to be poor, failing to meet the minimum learning requirements of acquiring basic skills and competence. Poor academic performance seems to be the order of the day as reflected in the students' examinations. For example, the SSCE'S result for 2010, 2011, 2012, 2013 and 2014 reveals that only $24.94 \%, 30.99 \%, 25.99 \%, 29.27 \%$ and $31.28 \%$ respectively of the candidates who sat for the examinations obtained five credits including Mathematics and English language which are required for admission into the Nigerian Universities.

Students' poor academic performance has for some time been attributed to teachers' ineffectiveness, poor intelligent quotient of the students and poor mental alertness of the students, with less or no reference to the effect of insecurity of the school environment and its related factors. Nevertheless, educators and psychologists have realized that many students perform poorly in their academic work not because they do not possess the mental ability to do well but because they may have been affected by the insecurity of the school environment. In this line, Ojukwu and Nwanma (2015) as well as Ojukwu and Onuoha (2016) have reported influenced respectively students' behavior and their psychosocial adjustment.

The concept of insecurity connotes the state or quality of being insecure. Security in simple terms means protection of lives and properties from destruction. According to Onifode, Imhonopl and Uorim (2013) security is the dynamic condition which involves the relative ability of a state to counter threats to its core values and interest and their primary beneficiaries are the citizens. In addition, sharing the view Abraham Maslow, Iyenger (1977) stated that an insecure person perceives the world as a life threatening jungle, feels unsafe, unhappy, rejected, hostile, and pessimistic, shows a sign of tension, conflict and guilt, and tends to be neurotic and generally egocentric. It therefore seems that when a 
student studies in an environment that is characterized by insecurity, the student may suffer socially, mentally and emotionally and it makes sense hypothetically to state that all these are likely to affect not only his behavior and psychosocial adjustment but may also affect his academic performance.

According to Ojukwu and Nwanma (2015), insecure school environment, including the dilapidated conditions and teachers' negative attitude to condone and accept the emotional needs of students, which will lead to undue influences and clashes of a local community interfering with school business. Also, they stated that in insecure school environments the psychological problems of the students are never met or carelessly handled, there are always segregations in the school community along religions, tribal and sectarian lines as students may ignore teachers' directives and may also challenge the teachers on certain concepts and school properties may likely be deliberately damaged by the students to show their disapproval of managements decisions (Ojukwu \& Nwanma, 2015).

Also Ojukwu and Nwanma (2015) reported that in a school environment characterized by insecurity, lateness is the norm in school and students are allowed to freely use handsets and phones. Annually, the external results of the school are always bad as a result of poor teaching climate of the school as having been shown by 2010, 2011, 2012, 2013 and 2014 WAEC results cited above. Other instances of insecurity of the school environment include that sometimes female staff and students complain of being raped or impregnated leading to school dropout (Ojukwu \& Nwanma, 2015). Also, parents complain that their children are bullied and injured and the classrooms are overcrowded, poorly ventilated and lit (Ghazi, Shahzada, Tariq \& Khan, 2013). The above painted school environment may most likely affect students' academic performance.

The levels at which the afore-mentioned variables can positively or negatively interact with each other in the school environment will usually help to make or mar teaching and learning which may affect students' performance. The end result is that it brings effectiveness in the classroom, enhances students' cooperation and learning, promotes love and efficient planning by the school authorities where it is positive and vice versa where it is negative (Ojukwu \& Nwanma, 2015 and Ojukwu \& Onuoha, 2016). Again the negative impact of the above painted variables may help to encourage low academic performance. Because of the negative effect the insecurity of the school environment may have on the academic performance of the secondary school students, this study has become necessary. Therefore, the focus of this study is to examine the effect of insecurity of the school environment on the academic performance of secondary school students in Imo state. The researcher with his students had in previous researches investigated the influence of insecurity of school environment on the students behavior and psychosocial adjustments in Abia and Imo states (Ojukwu \& Nwanma 2015; Ojukwu \& Onuoha, 2016) respectively. This present study is in furtherance of the former studies in this regard. The result of the findings will help proffer possible solutions to the prevailing and nagging problems of academic performance by our adolescents and students.

\subsection{Statement of the Problem}

Recently major stakeholders in Education such as government, industries, communities, parents, schools even students and many others have been lamenting over the poor quality of Nigerian students in both learning and character suggesting a poor academic performance. Researchers and authors have speculated reasons for the failure on the part of the Nigerian students in secondary schools including those in Imo state to acquire the necessary social, psychological and academic skills to cope with demands of life and living in and outside the school. Their findings and suggestions tend to point at those issues which tend to waste students' time and then have false notions about true life situations. Others have focused on teaching and learning materials as well as students themselves. An area that seems to have been neglected by past researchers is the effect insecurity of school environment will have on the academic performance of the secondary school students. Educators have long emphasized that many students perform poorly in their academic work not because they do not possess the mental ability to do well. An area that seems to have been neglected by researchers is the issue of insecurity of the school environment and the effect it could have on the academic performance of the secondary school students.

According to Ojukwu and Nwanma (2015), since the inception of democracy in Nigeria in 1999, insecurity has become a major issue of concern to every citizen. On a daily basis the media has continued to highlight and discuss incessant cases of armed robbery, kidnapping, bombings, abductions, rape, cultic activities and a high rise in ethnic and communal clashes, which have become regular occurrences and have characterized life in Nigeria (Nwangwa, 2014). Media report are awash with the number of lives lost as a result of terrorist, insurgent and other attacks that seem to be alarming. As if some places in the country can be walled off from the negative impact of violence, our academic (schools) institutions have also become hot spots where cases of insecurity are recorded (Ojukwu \& Nwanma, 2015). The main interest, motivation and problem of this study therefor is to investigate the effect of the insecurity of the school environment on the academic performance of secondary school students in Imo state.

Considerable attempts may have been made at researching on some variables or factors affecting students' academic performance but little or none has focused on the effect of insecurity of the school environment on the academic performance of secondary school students. Also, given the wide ranging effects of students' poor academic performance and its concomitant social and destructive emotional effects on the students, parents, society and the nation It is appropriate and should be a welcome development to investigate the effect of insecurity of the school environment on the academic performance of secondary school students with the view of proffering solutions for a better performance by students. 
1.2 Objectives of the Study

The objectives of the study were to:

1. Determine the factors that constitute insecurity of the school environment that may influence academic performance.

2. Determine the effect of insecurity of the school environment on the academic performance of secondary school students in Imo state.

3. Determine the statistical significance of the difference between the environment of insecurity of rural and urban secondary schools in Imo state.

4. Investigate the statistical significance of the difference between male and female students academic performance due to insecurity of the school environment in Imo state.

1.3 Research Question

The following research questions were raised to guide the study.

1. What are the factors that constitute insecurity of the school environment $t$ in Imo state?

2. What effect does school environment have on academic performance of secondary school students in Imo state?

1.4 Null Hypotheses

Insecurity of school environment does not significantly affect the academic performance of secondary school students in Imo state.

$\mathrm{Ho}_{1}$ : There is no significant difference in the insecurity of the school environment between secondary schools in rural and urban areas in Imo state.

$\mathrm{Ho}_{2}$ : There is no significant difference between male and female students' academic performance due to the insecurity of school environment in Imo state.

\section{Method}

\subsection{Research Design}

The study has a descriptive survey design that utilized questionnaires to obtain data from the respondents. It is a followup of two previous researches in this area by the researcher and his postgraduate students who have studied the influence of insecurity of school environment on the behavior of secondary school students in Isiala-Ngwa North and South Local Government Areas of Abia State, Nigeria (Ojukwu and Nwanma 2015) and influence of insecurity of the school environment on the psychosocial adjustment of secondary school students in Imo State, Nigeria (Ojukwu \& Onuoha, 2016). According to Nwankwo (2011) descriptive surveys aim at collecting data from a given sample of population and described probably certain features of the sample as well as generalizing them to the entire population. This study is regarded as a descriptive survey because the researcher collected data from a large sample of students from Imo state secondary schools. It described how insecurity of school environments affected academic performance of students in Imo state.

\subsection{Population of the Study}

The targeted population was all the senior secondary school students in the 27 Local Government Areas of Imo State who were in their Senior Secondary Class I (SSI) in the 2014/2015 academic year.

\subsection{Sample and Sampling Technique}

The sample of the study was 1000 senior secondary school students who were in their SSI and in the 2014/2015 academic session. They were made up of 500 each of males and females. The study made use of simple random sampling, proportionate stratified random sampling and purposive sampling techniques. Using proportionate stratified random sampling, 10 schools were selected from the 27 Local Government Areas of the State, 5 of which were located in rural areas while the remaining five were in the urban areas ensuring that at least 3 were selected from each of the three political zones of the State made up of Owerri, Olu and Okigwe. The remaining one that made it 10 was purposively selected from Owerri zone due to the large number of secondary schools in the zone. Through simple random sampling 100 students were selected from each school made up of 50 males and 50 females.

\subsection{Instrument for the Collection of Data}

The instrument used for the collection of data was a 25 item structured questionnaire entitled "Effect of insecurity of school environment on academic performance" (EISEAP). The questionnaire used a 4-point Likert method of strongly agree, agree, disagree and strongly disagree. It had 3 sections. Section A included demographic questions, section B comprised questions on insecurity while section $\mathrm{C}$ was composed of questions on relationship between insecurity and students' academic performance. The points of 4, 3,2 and 1 were assigned to each scale respectively in the questionnaire. Measure of academic performance was the academic achievement grades of the participating students in English language and Mathematics obtained from the examinations and records section of Examination Development Centre Owerri, Imo State of the participants Junior Public Secondary School West African Examination Council, 2013/2014 academic session which is a standardized examination. 
Copies of the questionnaire were given to three experts in the college of education (faculty) and from the Departments of Psychology, Guidance and counseling and Measurement and Evaluation of Michael Okpara University of Agriculture, Umudike to validate the instrument. The experts confirmed the appropriateness, comprehensiveness and clarity of the items in the questionnaire. Their constructive criticisms and opinions led to the restructuring of some items of the questionnaire which helped to strengthen the face and content validity of the instrument.

Its reliability was determined by administering the instrument to 100 students of the same class of SS1 from 5 schools that were not part of this present study. A re-test method with an interval of two weeks was followed to test the reliability of the instrument. The scores obtained were correlated using Person's Product moment co-efficient. An acceptable coefficient of $\mathrm{r}=0.78$ was obtained thereby indicating that the instrument was adequate for the study. Additionally, a Cronbach alpha value of $\mathrm{r}=0.88$ was recorded for the instrument indicating its acceptable internal consistency.

\subsection{Administration and Scoring of the Instrument}

The instrument was administered to the students with the assistance of three research assistants who were postgraduate students and four secondary school teachers from the participating schools. They were briefed on the administration procedure. The questionnaires were all collected, coded and scored. The data were analyzed using mean and standard deviation for the research questions while t-test was used to test the hypotheses. Mean cut-off point was 2.5. All items with mean of 2.50 were regarded as agreement and accepted while those less than 2.50 were regarded as disagreement and were accordingly rejected. In the analysis 'strongly agree' was merged with 'agree' while 'strongly disagree' was merged with 'disagree' to give 'disagree'.

\section{Results}

The findings of the study are presented below:

\subsection{Perception of School Insecurity Factors Affecting Academic Performance of Secondary School Students}

The first research question was, "What are the factors that constitute insecurity of the school environment in Imo State?" To establish factors that constitute insecurity of the school environment that may influence students' academic performance in Imo State, the respondents' mean scores and standard deviation were analyzed. The mean cut off used was 2.50. All items with mean 2.50 and above was regarded as agreement and accepted for the purpose of analysis as factors that constitute insecurity of the school environment that may affect students' academic performance of the senior secondary schools students' in Imo State.

Table 1. Mean rating and standard deviation of the factors constituting school environment insecurity that affect students' academic performance $(\mathrm{N}=1000)$

\begin{tabular}{lll}
\hline Insecurity Factors & M & SD \\
\hline 1. I have not suffered any form of bulling in my school & 3.45 & 1.04 \\
2. There is inadequate security in my school. The school compound is not fenced and protected. & 3.89 & 0.86 \\
3. Students' properties are not tampered with after school. & 3.40 & 1.04 \\
4. I have not been sexually harassed or raped in school by teachers or senior students. & 3.07 & 1.04 \\
5. I have not seen any students with guns within the school premises or outside school. & 3.08 & 1.03 \\
6. I have heard a gunshot around my school compound sometimes. & 3.42 & 0.72 \\
7. There is no manifest cult activities in my school. & 3.24 & 0.18 \\
8. Some students smoke Indian hemp and other hard drugs within the school compound & 3.64 & 0.92 \\
9. There are some student gangsters in my school whose activities affect and disrupt & 3.21 & 0.76 \\
10. I have heard of kidnapping from our school. & 3.20 \\
11. Students have been kidnapped from our school. & 2.62 \\
12. Parents had come to my school before to confront teachers who gave students corporal & 3.30 \\
13. There have been cases of violence and cult activities within our school. & 0.76 \\
14. There has been reported case of armed robbery attack in or near our school compound. & 3.01 \\
\hline
\end{tabular}


As stated above mean cut-off was 2.50 . All items with mean of 2.50 were regarded as agreement and accepted while those with less than 2.50 were regarded as disagreement and rejected. In effect the responses were either accepted or rejected as an insecurity factor that may affect academic performance.

Accordingly Table 1 above shows results obtained from answering research question 1 for the study. Following from the data on table 1 it could be safely concluded that some factors that constitute insecurity in the school environment in Imo State which may affect academic performance include: Inadequate security in the school environment inform of school compound not being fenced and protected with a mean of 3.89 and standard deviation of 0.86 , sporadic gun shots within and outside school compound 3.42 and 0.72 (mean and standard deviation respectively). Others include smoking of Indian hemp and other hard drugs by students within and outside school premises, mean 3.64, students' gangsterism which disrupts school activities, kidnapping of students and parents confrontation of teachers as a result of corporal punishment meted to their wards. Also there have been cases of violence, cult activities and armed robbery activities within and around school premises.

It should be noted that the items that were negatively constructed also received positive mean scores which means that they are equally factors that constitute insecurity of the school environment that may affect academic performance of secondary school students. Such factors include: bulling by senior students, tampering with school properties, sexual harassment or rape by teachers and senior students, manifest cult activities and students carrying guns within and outside school premises.

\subsection{Effect of Insecurity on Academic Performance}

The second research question was, "What effect does insecurity of school environment have on academic performance of secondary school students in Imo State?" To determine the effect of perceived insecurity of school environment on academic performance of the secondary school students, the students' respondents' mean responses, standard deviation were analyzed and the result of which is summarized in Table 2 below:

Table 2. Mean rating and standard deviation of effect of insecurity of school environment on the academic performance of the students $(\mathrm{N}=1000)$

\begin{tabular}{clc}
\hline As a result of perceived insecurity of the school environment ... & M & SD \\
\hline 1. I feel insecure in the school. & 3.03 & 0.61 \\
2. I have skipped school sometimes & 2.92 & 0.87 \\
3. I missed certain lessons those days I absented from school & 3.57 & 0.60 \\
4. those lessons I missed affected me in my examinations & 3.39 & 0.75 \\
5. I performed better in any session I did not miss school & 3.16 & 0.61 \\
6. anytime I feel secure, I am more attentive in class. & 3.44 & 0.54 \\
7. at times I avoid my teachers who have punished or sexually harassed me. & 3.01 & 0.57 \\
8. anytime my parents confront my teachers or harasses them, I experience set-back in & 2.94 & 0.76 \\
9. I will do better if my school environment is safe and secure. & 3.16 \\
10. students lose interest in school and academic activities. & 3.89 & 0.70 \\
11. students practice truancy which affects academic performance. & 2.98 & 0.87 \\
12. some boys join trading and girls get married and leave school as a result of poor & 3.30
\end{tabular}

Results from Table 2 show effect of insecurity of school environment on the academic performance of secondary school students. From the table it can be seen and concluded that as a result of perceived insecurity of the school environment students are afraid and feel insecure in the school, sometimes skipped school, mean 2.92; as a result missed certain lessons 3.57 which affects them in their examinations 3.39 .

However, students opined that they perform better when they did not miss school and that they pay better attention when they feel secure and perform better when they perceive a better, safe and secure school environment. Also students lose interest in school and academic activities as a result of perceived insecurity of the school environment, they also practice truancy and some boys leave school and take up trading while girls dropout and get married.

\subsection{Difference in the Insecurity of the School Environment between Urban and Rural Secondary Schools}

The first null hypothesis was, "There is no significant difference in the insecurity of the school environment between rural and urban secondary schools in Imo State." To verify the authenticity of the above hypothesis a t-test analysis was ran and the result of which is summarized in Table 3: 
Table 3. T-test analysis showing the difference in the insecurity of the school environment between rural and urban secondary schools in Imo State

\begin{tabular}{lllllll}
\hline Location of school & $\mathrm{N}$ & $\mathrm{M}$ & $\mathrm{SD}$ & $\mathrm{t}$ & $\mathrm{df}$ & $\mathrm{p}$ \\
\hline Urban & 500 & 26.56 & 5.92 & 4.59 & 998 & 0.04 \\
Rural & 500 & 24.95 & 5.87 & & & \\
\hline
\end{tabular}

The t-test revealed a significant difference between the scores of respondents from urban and rural secondary schools in Imo State. Consequently, the null hypothesis was rejected; it was concluded that there is a significant difference between insecurity of school environment between secondary schools located in urban and rural areas in Imo State with the urban secondary schools feeling more insecure.

\subsection{School Environment Insecurity and Male/ Female Student Academic Performance}

The final null hypothesis examined the difference between male and female students' academic performance due to the insecurity of school environment of their school environment.

The first null hypothesis was, "There is no significant difference between male and female students' academic performance due to the insecurity of school environment in Imo State Senior Secondary Schools." This hypothesis was also tested using independent samples t-test and the results are summarized in Table 4:

Table 4. Insecurity of School Environment, Academic Performance and Students' Gender

\begin{tabular}{lllllll}
\hline Gender & $\mathrm{N}$ & $\mathrm{M}$ & $\mathrm{SD}$ & $\mathrm{t}$ & $\mathrm{df}$ & $\mathrm{p}$ \\
\hline Males & 500 & 25.20 & 5.74 & 4.233 & 998 & 0.03 \\
Females & 500 & 26.48 & 6.50 & & & \\
\hline
\end{tabular}

The results indicated that female students' academic performance $(M=26.48, S D=6.50)$ was affected more than that of the male students $(M=25.20, S D=5.74)$ by the insecurity of the school environment. The t-test results $t(998)=4.233$, $\mathrm{p}<.05$ showed the insecurity of school environment will lead to significant differences between the academic performances of male and female students in Imo State.

\section{Discussion}

Findings from this study revealed that insecurity of school environment significantly affects the academic performance of secondary school students. Consistent with these findings, Grifft (1999) maintained that a sense of competency will often emerge in an environment that is fair and consistent which will in turn provide appropriate academic support and expectations. In this line, Glew et al. (2005) suggested that improving students' behavior and academic performance will generally require changing school environment.

The result also showed that the following are factors that could constitute insecurity of the school environment which affect academic performance: smoking of Indian hemp and other hard drugs by students within and outside school premises, students' gangsterism, cult and violent activities which disrupt school activities as well as kidnapping, students and parents confrontation of teachers in school and outside as a result of teachers meting out corporal punishment to the students. Other factors include sexual harassment, rape, becoming bullied by the senior students, students carrying and shooting guns within and outside school premises and finally armed robbery attacks within and around school premises. The process through which these could affect academic performance of the students' cannot be over emphasized. According to Lehr (2004), the noble goals of education can never be achieved in a vacuum. They would be achieved in a conducive and peaceful school environment and if there is a feeling of insecurity within and outside the school environment both teachers and students are likely to be afraid and this may inhibit academic performance of the students. In addition, a situation where parents confront teachers in school will affect academic support which students are expected to receive from their teachers. Wang (2010) stressed that students' who perceive strong academic support in school are more likely to be academically motivated as they perceive that their teachers are supportive, responsive and care about them hence higher motivation and better academic performance.

Other findings of the study showed that as a result of the school environment students are afraid and feel insecure, skip school, miss certain lessons which affect them during their examinations. Besides, they lose interest in school and academic activities which leads to truancy as well as boys leaving school to take up to trading while girls drop out and settle for married life because they feel insecure within their school environment. This finding lends credence to the finding of Ojukwu and Nwanma (2015) who reported that as a result of insecurity of the school environment that sometimes female staff and students complain of being raped or impregnated leading to their being dropped out of school.

Findings also reveal a significant difference between insecurity of school environment between secondary schools located in urban and rural areas. Urban secondary school students feel more insecure than students in schools located in 
the rural areas. This finding is not surprising because in Nigeria crimes and insecurity are more pronounced in the urban areas than in the rural areas.

Finally, the study showed that insecurity of the school environment has a significant effect on the academic performance of male and female students. This finding also supports the findings of Ojukwu and Nwanma (2015) who reported after individual analyses of the items in their questionnaire that more girls were involved in premarital sex, rape and suicidal attempts than boys. Girls also usually suffered more from emotional trauma and depression due to failure than the boys. They also suffered from sexual attacks by male teachers and their follow male students (Ojukwu \& Nwanma, 2015). All the above will certainly affect female students' enrolment as well as their academic performance.

\section{Conclusion and Recommendation}

In conclusion, the results from this study have extended and called for more research regarding insecurity and the school environment vis-a-vis students' academic performance. Students' poor academic performance has for some time been attributed to factors such as teacher's ineffectiveness, poor intelligent quotient of the students, and poor mental alertness of the students among others with less or no reference to the effect of insecurity of the school environment and its related factors. However, in the global search for the poor academic performance of Nigerian secondary school students, educators and psychologists have realized that many students perform poorly in their academic work not because they do not possess the mental ability to do well but because they have been affected by other factors. Hence, this study investigated the effect of insecurity of school environment on the academic performance of secondary school students in Imo State.

Major findings showed that insecurity of the school environment significantly affects the academic performance of secondary school students while smoking of Indian hemp, hard drugs, student's, cult, violent activities, kidnapping, armed robbery, parents confrontation of teachers, sexual harassment, rape, using of guns and bullying of junior by senior students among others are major factors that constitute insecurity of the school environment. As a result of the insecurity of the school environment, students become afraid of school as they feel insecure and hence they skip school, miss lessons which eventually affect them during examinations. Besides, they lose interest in school and academic activities which eventually lead to truancy and boys leaving school to take up trading while girl's dropout and settle for marriage. It was also revealed that there is a significant difference in insecurity of the school environment between schools located in urban and rural areas while insecurity of the school environment has significant effect on the academic performance of male and female students.

Based on the findings of this study, efforts should be made by owners of schools as well as stake holders in education to ensure that school environments are fenced and protected to ward off intruders from the school premises so that students can have a sense of security which will allow them to concentrate and improve on their academic performance.

\section{References}

Fehintola, J.O. (2009). The effect of family background and environmental factors on Academic achievement of secondary school students: A study of selected secondary school students in Saki West Local Government Area. International Journal of Distance Education, 4, 51-64.

Ghazi, S.R.; Shahzada, G., Tarig, M., \& Khan, A.O. (2013). Types and causes of students, Disruptive Behaviour in classroom at secondary level in Khyber Pakhtunkhwa, Pakistan. American Journal of Educational Research, 1(9), 350354.

Glew, G.M., Fan, M.Y., Katon, W., Revera, F.P., \& Kernic, M.A. (2005) Bullying, Psychosocial adjustment and academic Performance in elementary school.Archives of Pediatric and Adolescent Medicine, 159, 1026 - 1031

Griffit, J. (2000). School climate as "Social order" and "Social action"; A multi-level analysis of public elementary school student perceptions. School Psychology of Education 2, 339 - 369

Iyenger, B.K.S. (1977). Emotional Security. Retrieved on 30/7/2015 from http://www.wikipedia online.com

Kuperminc, G.P., Leadbeater, B.J., \& Blatt, S.J. (2001). School Social Climate and individual differences in Vulnerability to psychopathology among middle school students. Journal of School Psychology, 39(2), 141 - 159.

Lehr, C.A. (2004). Positive School Climate; Information for Education. National Association of School Psychologists. Retrieved on 26/7/2015 from http://www.nasponline.org/.../school-climate-hopd s

McEvoy, A \& Werner, R. (2000). Antisocial behavior, academic failure, and school climate: A critical review. Journal of Emotional and Behavioural Disorders, 8(3), 130 - 140.

Miller, A. and Cunnighan, K. (2011). Classroom Environment. Retrieved on 30/07/2015 from www.education.com/.../classroom

Morgans, K. A. (2002). The social and Academic Adjustments of students to college life. Retrieved on 04/10/2009 from http:clearinghouse.misscourl-western.edu 
Mudege, N.N., Eliya, Z. M and Izugbara, C. (2008). How insecurity impacts on school Attendance and Dropout among urban Slum Children in Nairobi. International Journal of Conflict and Violence, 2(1), 98-112.

Nwangwa, K.C.K. (2014). Controlling the Security Challenges in Nigeria. The Managerial Perspective. A Lecture Presented at the Distinguished Lecture/Management Luncheon Day for Institute of management of Nigeria, Abia Chapter.

Nwankwo, O.C. (2011). A practical Guide to Research Writing for studies of Research Enterprise (4 ${ }^{\text {th }}$ Eu). Choba: Pam Unique Publishers

Nwanna-Nzewunwa, O.P. (2009). Sociology of Education for Certificate and Diploma Students. Port Harcourt: Springfield publishers Limited.

Obi, T.E.C., Johnson, H.I. and Lawani .C. (2014).The School Environment and the child. Lagos: National Open University of Nigeria.

Ojukwu, M.O. and Nwanna, A.C. (2015).Influence of Insecurity of School Environment on the Behaviour of Secondary School Students in Isiala-Ngwa North and South Local Government Area of Abia State, Nigeria. International Journal of Education \& Literacy Studies, 3(4), 49 - 55.

Ojukwu, M.O. (2016). Perception of students on causes of poor performance in chemistry in External Examinations in Umuahia North Local Government Area of Abia State. International Journal of Education and Literacy Studies. 4 (1) $67-73$.

Ojukwu, M.O. and Onuoha, R.C (2016) Influence of Insecurity of School Environment on the Psychosocial Adjustment of Secondary School Students in Imo State, Nigeria. Journal of Sustainable Agriculture and the Environment 15 (3) in press.

Olofintoye, T.T. (2005). Psychosocial Adjustment of Integrated Secondary Schools. Boys and Girls: Implications for teacher Education Programmes. Pakistan Journal of Social Sciences, 5(7) 681 - 685.

Wang, M.T. (2010). Adolescents' Perceptions of School Environment, engagement and academic achievement in middle school. American Educational Research Journal, 47, 663 - 672.

Way, W., Reddy, R., \& Rhodes, J. (2007) Students' Perceptions of School Climate during the middle school years: Associations with trajectories of psychological and behavioral adjustment. American Journal of Community Psychology $40,194-213$.

Ossat, S.D. (2012). Philosophy of Education: An Assessment $3^{\text {rd }}$ Ed. Port Harcourt: SHAPEA Publishers Ltd.

West African Examination Centre (2016). Statistical release of Senior Secondary Result. SEMB, Umuahia, Abia State. 